\title{
Perception of Improving English Language Proficiency Through Video Compositions Among Male and Female Students of MRSM Kuala Krai
}

\author{
Isolde Hon Pei Sha (Corresponding author) \\ Department of Language and Humanities Education, Faculty of Educational Studies \\ Universiti Putra Malaysia, 43400 UPM Serdang, Selangor, Malaysia \\ E-mail: peisha1213@hotmail.com \\ Seyed Ali Rezvani Kalajahi \\ Department of Language and Humanities Education, Faculty of Educational Studies \\ Universiti Putra Malaysia, 43400 UPM Serdang, Selangor, Malaysia \\ E-mail: ali.rezvani85@gmail.com \\ Jayakaran Mukundan \\ Department of Language and Humanities Education, Faculty of Educational Studies \\ Universiti Putra Malaysia, 43400 UPM Serdang, Selangor, Malaysia \\ E-mail: jayakaranmukundan@yahoo.com
}

Doi:10.7575/aiac.alls.v.5n.4p.42

Received: 13/04/2014

URL: http://dx.doi.org/10.7575/aiac.alls.v.5n.4p.42

Accepted: 17/06/2014

\begin{abstract}
Videos are very versatile. They can act as a tool for listening that enhances listening experience for our students. Other than that, the actions, gestures, emotions, settings, etc, that is observed by students in a video can provide significant visual stimulus for the practice and production of the English language. The study also considers the students perception of improving their English language proficiency through video composition. This research adopts a quantitative approach to establish relationships between variables and to explain the how they are related to each other. To this end, 110 students of Form 4 in MRSM Kuala Krai, Kelantan were involved in this study. Upon data collection, we analyzed the students' attitudes towards the conventional teaching classroom, video composition project, and also new teaching methodologies. Besides, we also discussed the significant difference between the perception of both male and female students of Form 4 in MRSM Kuala Krai, Kelantan.
\end{abstract}

Keywords: Language proficiency, video composition, MRSM Malaysia

\section{Introduction}

\subsection{Research Background}

The English language is the language of international communication and it is used as a second language in Malaysia. In accordance with the trends of globalization, the knowledge and the practice of the English language becomes more crucial for us to survive in a nation of rich diversities. Therefore, Malaysian students should be well trained and equipped with a strong foundation in English. This is to ensure better student marketability and higher competence in the English language.

Since English is a second language in Malaysia, it is extensively used in primary up to the tertiary level in our education system. English language is also widely used in numerous professions such as medical, legal, engineering and business. Thus, Malaysian students need to be proficient in the English language so that they will be able to use English effectively for academic purposes and also in professional settings in the future.

As a conclusion, it is important that our Malaysian students master the use of English, as it helps students to excel in terms of academic and also prepares them for the competitive job market. In order to compete with others in the professional setting, students will not only need good academic results, but also the ability to communicate in the English language. Those who are proficient in the language will very much likely be chosen as they meet the demands of globalization (Hagener, Malte, \& Töteberg, Michael, 2002).

Films are a type of visual entertainment and therefore, films are usually considered to be an important art form, a source of popular entertainment and a powerful method for educating or indoctrinating citizens. Integrating short films or videos into lessons creates engaging visuals and also an interactive environment in the ESL classroom. Teaching 
English using videos allows teachers to be creative when designing language lessons. As Cundell (2008) states, "One of the most powerful ways that video can be integrated into courses is for the visual representation they provide for learners on otherwise abstract concepts."

Teaching the English language skills through drilling exercises and the traditional fill-in-the-blank, and multiple-choice assessments do not interest our students as much as we expect. Planning and carving specific lessons for different language skills can be challenging and time consuming for English teachers, but it is definitely worth the effort. Although the process of creating a video may be long and complicated, the results are much more significant.

Most teachers would use existing videos as teaching materials in classrooms. Only a small number of teachers had conducted a video composition class before. Instead of asking students to view a projected video, it would be a good change to see students themselves working on their own video composition to convey messages that they want to convey or according to an assigned theme.

In this research, we will be looking at the perception of improving English Language Proficiency among male and female students of Form 4 at Mara Junior Science College (MRSM Kuala Krai). This will be the target group as this group of students has already produced videos of their own for an English week program under the supervision of a few selected ESL students from Universiti Putra Malaysia.

\subsection{Research Problem}

The average Malaysian student would have been exposed to the learning of the English language as a second language formally for at least 11 years (Primary 1 - Secondary 5) in school. This would mean that Malaysian students should have been given great exposure towards the practice and application of English language in school for such a long period of time. Unfortunately, despite the lengthy years of English language learning, many students still have difficulty to use English effectively. Other than being influent in English, most (where their mother tongue is their first language) are reluctant to speak.

Teaching the English language skills through drilling exercises and the traditional fill-in-the-blank, and multiple-choice assessments do not interest our students as much as we expect. Planning and carving specific lessons for different language skills can be challenging and time consuming for English teachers, but it is definitely worth the effort. Although the process of creating a video may be long and complicated, the results are much more significant.

Video is always seen as a source of entertainment, never a potentially good English language material. Little do we know that this possibly underused classroom tool can help students to improve their English language proficiency in many ways.

Until today, quite a number of English teachers who are aware of this matter had taken the chance of using videos in class. Many use it as a way to gain students' attention in classrooms and use it as set inductions to teach core contents.

Videos are very versatile. They can act as a tool for listening that enhances listening experience for our students. Other than that, the actions, gestures, emotions, settings, etc, that is observed by students in a video can provide significant visual stimulus for the practice and production of the English language.

\subsection{Research Questions}

In this research, the research questions are:

1) What is the difference between male and female students' attitude towards the conventional English teaching classroom?

2) What is the difference between male and female students' attitude towards the video composition project?

3) What is the difference between male and female students' preference towards improving English language proficiency through video composition compared to the conventional English teaching classroom?

\subsection{Hypothesis}

The hypothesis of this study is null. Male and female students will show no significant difference between each other in terms of perception and attitude towards the conventional teaching classroom, video composition project and new teaching methodologies.

\subsection{Significance of Research}

This study is important not only to the teachers, but also every other party or institution directly or indirectly involve with the development of our students education such as the parents, curriculum developers, and the Ministry of Education. They need to have knowledge and understand the hindrance that our students' are facing in learning the English language in order to help and prepare them in developing better competency in the target language. Hence, it is only relevant that students' attitude towards certain teaching methodologies are identified to ensure a more effective teaching and learning process is carried out in the classrooms.

\subsection{Research Scope and Limitations}

The sample population will only be from among MRSM Kuala Krai students. The respondents will be 110 Form 4 students currently studying in MRSM Kuala Krai (2012). The limitation of this research would be the small number of respondents could only account for the trends of English language learning in MRSM Kuala Krai. It may not be suitable to relate the results of this study to other schools where they might be influenced with a different environment, plus the different learning and teaching experiences and methods. 


\section{Literature Review}

\subsection{Definition of Films}

A video, also called a short film or motion picture, is a series of still or moving images. It is produced by recording photographic images with cameras, or by creating images using animation techniques or visual effects (Hagener, Malte, \& Töteberg, Michael, 2002). The process of filmmaking has developed into an art form and industry. Films are cultural artifacts created by specific cultures, which reflect those cultures, and, in turn, affect them. Film is considered to be an important art form, a source of popular entertainment and a powerful method for educating or indoctrinating citizens. The visual elements of cinema give motion pictures a universal power of communication. Some movies have become popular worldwide attractions by using dubbing or subtitles that translate the dialogue into the language of the viewer.

\subsection{The Role of Movies and/ or Short Films}

Kelly and Watson (1986) pointed out that movie or short films (videos) is perceived as entertainment and is usually use outside the classroom context. Then, people never realized that movies have the potential to assist learners in learning the target language. However, it can be used as a teaching tool, method or approach to enhance learning experience especially in literature classrooms. In language learning, especially speaking, students' confidence is one of the factors to improve their learning. (Dornyei, 2001) suggested the ways to promote students' confidence were through providing experience of success, encouraging the learners and reducing anxiety. When students are confident in the language, they can fare better when they asked to perform in the language.

Movies can also be considered as a form of text. They are controllable teaching instruments, and offer great variety of subject, communicative language, language environment, and cultural content (Wood, 1995). The research findings from Lommel (2007) states that before the experiments began, some participants explicitly received some of the foreign grammatical rules (presented rules), while the movie contained cases of presented rules as well as cases of rules which had to be inferred (not-presented rules). Therefore the movies shown in our research will not be something that is beyond their grasp so that they can be able to decipher the message and also learn the language.

There is a difference between the language we use in formal classrooms and the spoken language from the movies. Some people can perform well in the written language but are unable to produce authentic spoken language. Watching movies will enable the students to be more confident during speaking the language. Murray (2003) saw that "video can show learners how to use language in socially appropriate ways and demonstrate conversation strategies". Mill (1999) felt that "students enjoyed learning by watching an English movie. She thought it was a rewarding language learning experience for students".

Briggs-Evison (2006) considered that English speaking films and television programs provide a rich source of real, natural English. Film can also allow many more characters speaking at the same time than an audiotape. Students also need to develop more confidence in their ability to make informed guesses about what people are actually saying in English movies. It not only provides authentic material to comprehend western culture but also shows how to pronounce vocabulary. Furthermore, it can motivate students to express ideas in English. This will indirectly lead them to be able to perform well in the speaking performance in ESL classrooms.

When students' communicative competence is increased, their confidence in language learning, especially speaking, increased as well (Dornyei, 2001). The more they practice speaking, the more their competence will increase because watching movies can motivate them to speak the language. Research by Herron, Hanley and Cole (1995) indicates that "the visual support in the form of descriptive pictures significantly improved comprehension scores with language videos for English speaking students learning French. The results of the study indicate that extensive listening is facilitated by the richness of the context that visual organizers, such as educational videos, provide". Heron (1994) finds that "advanced organizers based on videos helped learners improve comprehension and aid in the retention of information".

Arthur, (1999) claims that, "video can give students realistic models to imitate for role-play; can increase awareness of other cultures by teaching appropriateness and suitability; can strengthen audio/visual linguistic perceptions simultaneously; can widen the classroom repertoire and range of activities; can help utilize the latest technology to facilitate language learning; can teach direct observation of the paralinguistic features found in association with the target language; can be used to help when training students in ESP related scenarios and language; can offer a visual reinforcement of the target language and can lower anxiety when practicing the skill of listening." Therefore the movies chosen will be reasonable and also to enhance their speaking performance and comprehension in the language.

Videos can make the task, situation or language more authentic. More importantly, video can be used to help distinguish items on a listening comprehension test, aid in the role of recall, help to sequence events, as well as be adapted, edited or changed in order to meet the needs of the language learner (Canning, 1998). Research in second language acquisition (SLA) has shown that if learning is to be effective and permanent, it must be meaningful, involve active mental processes, and be reliable with the existing knowledge in the learner's mind (Hanley, Herron, \& Cole, 1995). Materials chosen for the watching of movies are carefully selected to that it can be as authentic as possible so that students will find it useful and interesting.

Killen (1998) stated that "the greater the amount of time students spend actively working on a subject and thinking about it, the greater their learning." Sjoberg (2006) added, “... the more people appear to be having fun, the greater the level of participation, regardless of any language difficulties". Both this researchers provide evidence that correlates 
with our research because it shows that as students spent more time watching movies or videos, their speaking skills will indirectly increase. Besides watching movies are usually a fun thing to do because it can provide a sense of enjoyment so the students won't be stressed to learn the language.

Moreover, (Edge, 1993) also supported this idea, "The more students use their language skills for enjoyment, the more language ability they are likely to acquire." Edge (2003) states that an action research just like how we are conducting is a rigorous investigation which sets out to improve the quality of experience and outcome available to participants in a given situation, while also enhancing their ability to articulate an understanding of what they have learned, thus increasing their potential to continue to develop in this and other situations, as well as contributing to the sources of knowledge available to others. Therefore, when we give them input especially on watching movies, they can increase their potential in the target language especially in terms of speaking.

\subsection{Benefits of Videos}

Videos produced by students can benefit both the students and the school in many ways. Some may think only the students who are involved in the process would get all the advantages of the English language content and medium of communication, but little do many know that, these students are also at the same time creating feasible classroom materials for the teachers. (Vincent, 2010) At OAHS, the video technology area has become a breeding ground for brand new ideas and students with talent. Most of my colleagues also find my lab exciting to use, and the school has now an average number of competent students in every classroom who can help teachers with classroom media needs.

Video composition is now considered as an important media of education. It is more widely used nowadays in conjunction the advancement of media technology (Vincent, 2010). My video classes are a community and district focal point for media needs. My students are learning technology at the highest level and at the same time addressing growing needs within district schools and community. Many of my level 2 and 3 students have advanced to universities and internships that lead to careers in the broadcasting industry.

Video compositions also promote team work and discipline as it requires the individuals to work together during the process of the composition. Moreover, it also brings the team together regardless of their levels of proficiency as the task is more technical and hands-on than of challenging their language competency. Thus, it lowers the students' anxiety during their participation in the video composition project.McKenney and Voogt (2011) Students' engagement in the development of media products has been said as a great way to promote individual and collective learning, and to establish a sense of community within the classroom, possibly even helping to bridge social boundaries and class barriers.

\subsection{Conventional Classroom Teaching}

Many have opinions about the conventional classroom teaching. In this modern era that we are living in, many conventional practices are seen as obsolete by the younger generation of students. (Kennedy, 2005) mentioned that the practices that the teachers devise in the teaching environment are often criticized, while having different reformers focusing on various problems. Some think of the process of learning as dull and dreary, while some think that classroom life as boring, uninteresting, unimportant, or unsubstantial.

Waller (1932) stated that the subject matter used in school was boring and irrelevant to the real world outside of the classroom. Decades later, Hoetker and Ahlbrand (1969) reviewed a number of studies in which the studies showed that teachers depended a lot on recitations that focused on insignificant facts and did not allow the students the opportunity to think about the content. Here we can see that many teachers are still unaware of the teaching methods used in classrooms no longer engage the students attention. Thus, students find learning to be something that requires too much effort and unappealing.

Students should be given tasks that they can relate to. Inauthentic tasks will deny the students opportunity to relate to their real life experiences, and they may most probably not feel passionate about what they are doing. Kilpatrick (1918) argued that the central feature of school life is the purposeful act where he wanted classroom lessons to be conducted according to the projects that students wanted to do. All these that are mentioned would allow students to be more engaged as the students find it more meaningful and will be able to relate to the activities better than the sort of learning activities that the teacher normally conducts or assigns.

\section{Research Methodology}

\subsection{Research Design}

This study is a quantitative survey research. It aims to establish relationships between variables and to explain the how they are related to each other. Other than that, this study also uses the co-relational. By using this approach, the relationship between two or more variables is determined and this does not require any sort of manipulation or intervention. Hence, in this method, the researchers only have to administer the instruments which are necessary in order to collect the required data.

This research also involves descriptive. According to Seliger and Shohamy (1990), descriptive research is a method that involves a collection of techniques used to specify, delineate or describe naturally occurring phenomena without experimental manipulation. This method is important because it allows the researcher to conduct the research without any alteration where the subjects will not be manipulated in any way. 
The adoption of these approaches was necessary because this research only wanted to identify male and female students' perception of the conventional English teaching classroom, the video composition project that they have done, as well as their preference towards the conventional classroom compared to the video project. No intervention was done throughout the research; therefore an experimental research was not necessary.

Self-administered survey or questionnaire is used to conduct this study. By using the survey method, it allows the researcher to collect the data in a shorter period of time if compared to interviews (Cresswell, 2003). In addition to that, surveys also allow the researcher to distribute to large numbers and collect data from all the participants at the same time. In conclusion, the survey method seems to be the best method for obtaining the kind of information this study seeks.

\subsection{Population And Sampling}

This research uses non-probability sampling which is purposive sampling. The researcher chooses the sample based on who they think would be appropriate for the study. The samples are selected because they are accessible to the researcher. Subjects are chosen simply because they are easy to recruit. This technique is considered easiest, cheapest and least time consuming. The researcher will select 110 students from the entire population of Form 4 MRSM Kuala Krai students. The reason for using a purposive sampling is to make sure that the samples that are chosen are the ones who had actually took part in video composition before. These students have accomplished two video composition projects where they are asked to compose videos following the given theme. The first theme is 'favourite music video' and the second is 'social issues among young adults'. In addition, the selection of the entire population is made so that the data collected will not be bias towards only a small amount of respondents. Besides that, the number of male and female students are equal, 55 students for each gender. Thus, there will not be a gender biased result in the data analysis later in this research. Collection of data from insufficient respondents might cause the research results to be invalid.

\subsection{Research Instrument}

This research is to examine male and female students' views on their perception of using video composition to improve English language proficiency. Their views and suggestions will be collected using the questionnaire in Appendix 1.

The research instrument is a self-administered questionnaire that is divided in to 3 sections, namely Section A, Section $\mathrm{B}$ and Section C. The instrument uses Likert Scale data collection where the score of (1) is strongly disagree, (2) is disagree, (3) is agree and (4) is strongly agree. Section A requires students to state their opinions about their interest in English as a subject and the conventional classroom teaching before the video composition project was conducted. As for Section B, students are asked to state their opinion about the video composition project that they have participated in. Last but not least in Section C, students are asked to state their opinions about the conventional classroom teaching compared to the video composition project after they have participated in the video composition project.

\subsection{Instrument Reliability And Validity}

The questionnaire used in this research is reliable as the analysis of the data collection is objective. Subjects will be given choices and they will select their preference. Each question's answer will be taken literally as there is no chance of personal or bias evaluation for the answers selected by the subjects.

For this study the reliability is tested using the SPSS version 1.7's reliability analysis. In the reliability analysis, Cronbach's Alpha is used to test the reliability of the instrument. It is mentioned by (Cronbach, 1951) that Cronbach's Qe(alpha) is a coefficient of internal consistency. It is used commonly as an estimate of the reliability of a psychometric test for a sample of examinees. Table 3.4.1 shows the result of the reliability test done on the research instrument.

Table 3.4.1 Cronbach's Alpha reliability statistics

\begin{tabular}{lcc}
\hline \multicolumn{3}{c}{ Reliability Statistics } \\
$\begin{array}{ll}\text { Cronbach's } \\
\text { Alpha }\end{array}$ & N of Items \\
& & \\
& $\mathbf{. 7 9 0}$ & 15 \\
\hline
\end{tabular}

The alpha coefficient for the 15 items in the instrument is .790 , suggesting that the items have relatively high internal consistency. (Note that a reliability coefficient of .70 or higher is considered "acceptable" in most social science research situations.)

As for validity, the questionnaire is validated by Assoc. Prof. Dr. Arshad Abd. Samad who has 22 years of teaching experience in the field of Teaching English as a Second Language (TESL). He holds a doctoral degree from Northern Arizona University, Flagstaff, Arizona, USA which he received in 1999 and Master and Bachelor degrees from Indiana University, Bloomington, Indiana, USA. He is involved in research and publication in the field of Teaching English as a Second Language (TESL), especially in grammar instruction, language acquisition and testing. He was appointed as a lecturer with University Putra Malaysia in 1990. He is also involved in various levels of consultancy work including programme evaluation of several local universities as well as for government and private agencies. Among his publications are Essentials of Language Testing for Malaysian Teachers (2002) dan Perspectives of Grammar in Education (2003). 


\subsection{Methods of Data Analysis}

The recorded data will be analyzed using the SPSS software version 1.7. Based on the data collected for this research, descriptive statistics will be used to determine whether the students feel that the use of video composition has aided their proficiency in the English language.

\section{Findings}

This section presents and discusses the findings on the three research questions of this study. A total number of 110 Form 4 students participated in this study. These students answered a 15 -item questionnaire which was an original piece validated by one of the experienced lecturers, who has almost 25 years of teaching experience in the field of Teaching English as a Second Language (TESL), especially in grammar instruction, language acquisition and testing in Universiti Putra Malaysia.

The data obtained is presented in four sections in order to answer the research questions of this study. Section A will discuss about the findings that answers the first research question of this study. Section B on the other hand will discuss the findings to answer the second research question of this study. Besides that, Section $\mathrm{C}$ will discuss about the analyzed data that answers the third research question of this study. All the above findings will be presented on simple bar graphs with numbers. Last but not least, Section D will show the related statistical measures which includes mean, standard deviation, and independent $\mathrm{t}-$ test.

At the end of this research, we will discuss whether the hypothesis of this research will be accepted or rejected.

\subsection{Findings of the First Research Question}

Figure 4.2.1. shows the distribution of male and female students' attitudes towards liking English as a subject in the classroom. $\mathrm{N}=45(40.9 \%)$ male students either agree or strongly agree that they like English as a subject, while $\mathrm{N}=50$ $(45.5 \%)$ female students also either agree or strongly agree that they like English as a subject in the classroom. The female scored the highest for liking English as a subject. Other than that, there are $\mathrm{N}=10(9.09 \%)$ male students who either disagree or strongly disagree with liking English as a subject while the female students show only $\mathrm{N}=5$ (4.54\%) of disagreement to the statement above. Thus, more male students disagree with the liking of English as a subject in the classroom compared to female students.

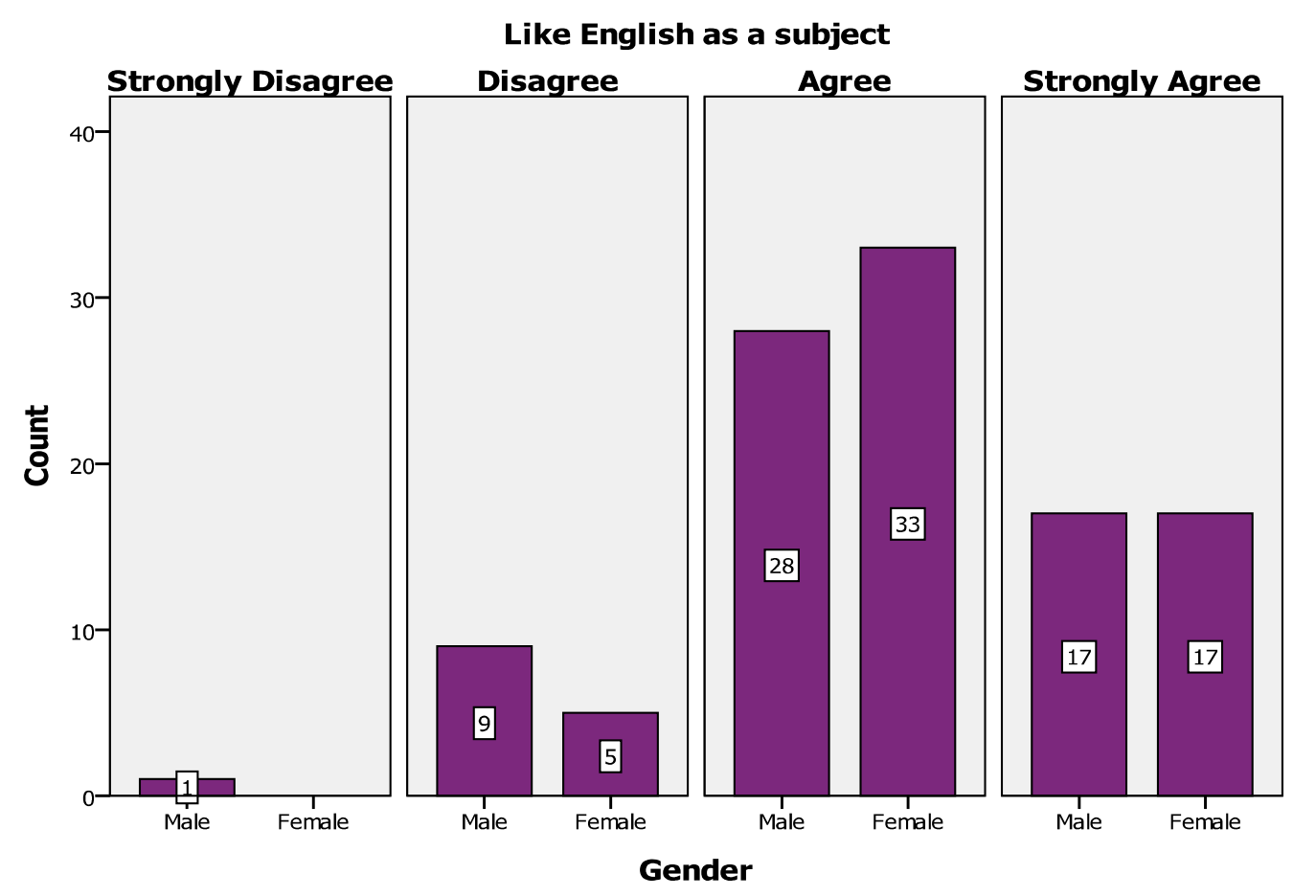

Figure 4.2.1. Distribution of male and female students' attitudes towards liking English as a subject in the classroom

Figure 4.2.2. shows the distribution of male and female students' attitudes towards whether or not they enjoy the way(s) of learning English in class. $\mathrm{N}=38(34.5 \%)$ male students show that either agree or strongly agree that they enjoy the way(s) of learning English in class, while the female students contribute $\mathrm{N}=39(35.5 \%)$ of the preference for either agree or strongly agree. Thus, the female students show a higher score of agreement. On the other hand, $\mathrm{N}=17(15.5 \%)$ male students disagree or strongly disagree, meaning that they do not enjoy the way(s) of learning English in class, while the female students contribute $\mathrm{N}=16(14.5 \%)$. Hence, the male students show higher tendency of not enjoying the way(s) of learning English in class. 


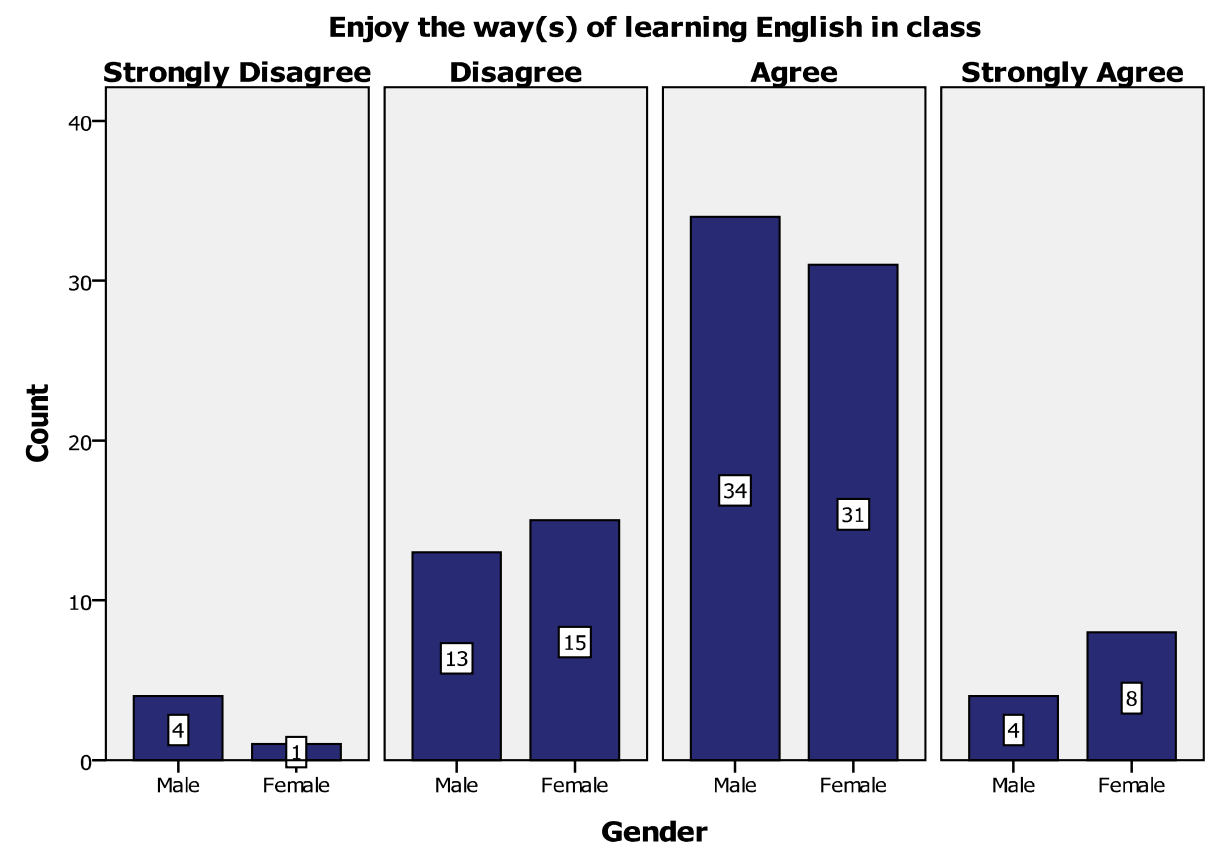

Figure 4.2.2. Distribution of male and female students' attitudes towards the conventional English classroom learning

Figure 4.2.3. presents the distribution of male and female students' attitudes towards their motivation to learn English through the conventional ways in the classroom. $\mathrm{N}=35(31.8 \%)$ male students and $\mathrm{N}=38(34.5 \%)$ female students either agrees or strongly agrees that conventional classroom learning motivates students to learn English. Besides that, there are $\mathrm{N}=20(18.1 \%)$ male students who either disagrees or strongly disagrees that the conventional classroom motivates English language learning, while the female students contribute $\mathrm{N}=17$ (15.5\%) to the disagreement of the variable mentioned above. Thus, more male students compared to female students, disagree that the conventional classroom motivates them to learn English.

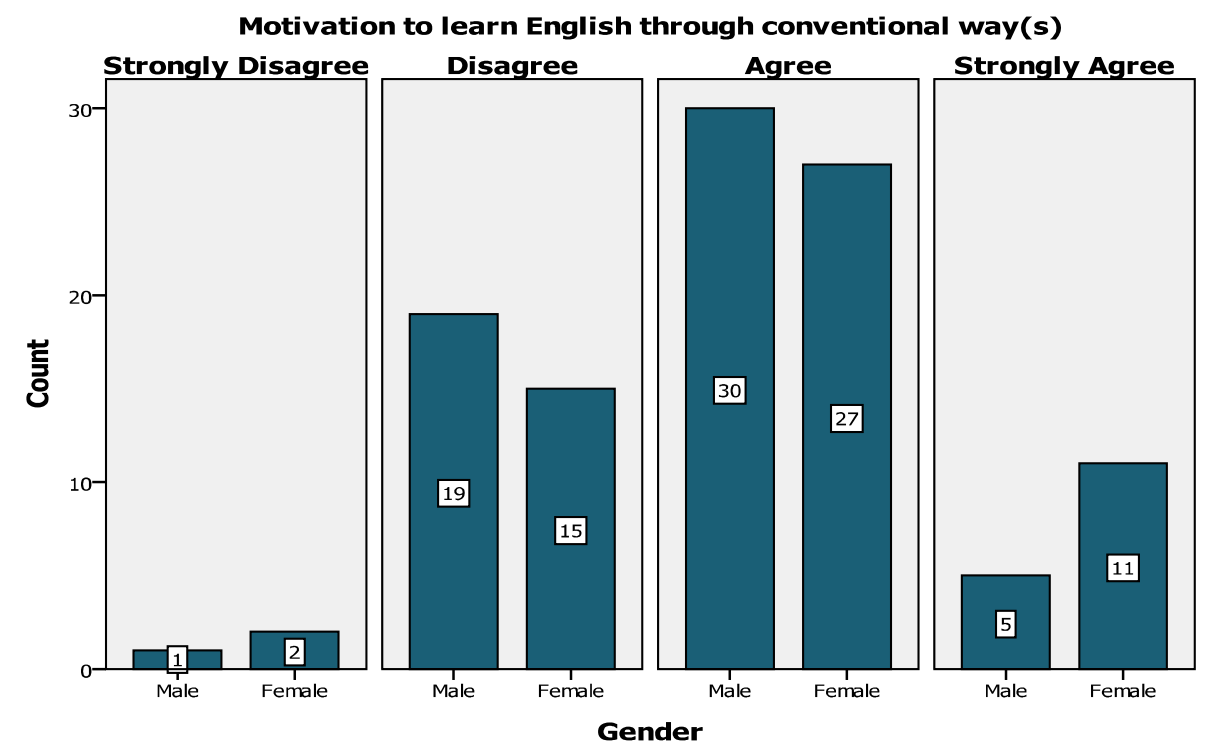

Figure 4.2.3. Distribution of male and female students' attitudes towards their motivation to learn English more in the conventional ways

Figure 4.2.4. presents the distribution of male and female students' attitudes towards improving their English language proficiency through conventional classroom learning. $\mathrm{N}=25$ (22.7\%) male students and $\mathrm{N}=28(25.4 \%)$ female students either agree or strongly agree that they can improve their English language proficiency through conventional classroom learning. This shows that female students agree more on the improvement of their English language proficiency through conventional classroom learning. On the other hand, $\mathrm{N}=30(27.2 \%)$ male students and $\mathrm{N}=27(24.5 \%)$ female students either disagree or strongly disagree. Here, it shows that more male students disagree with the improvement of English language proficiency through conventional classroom learning. 


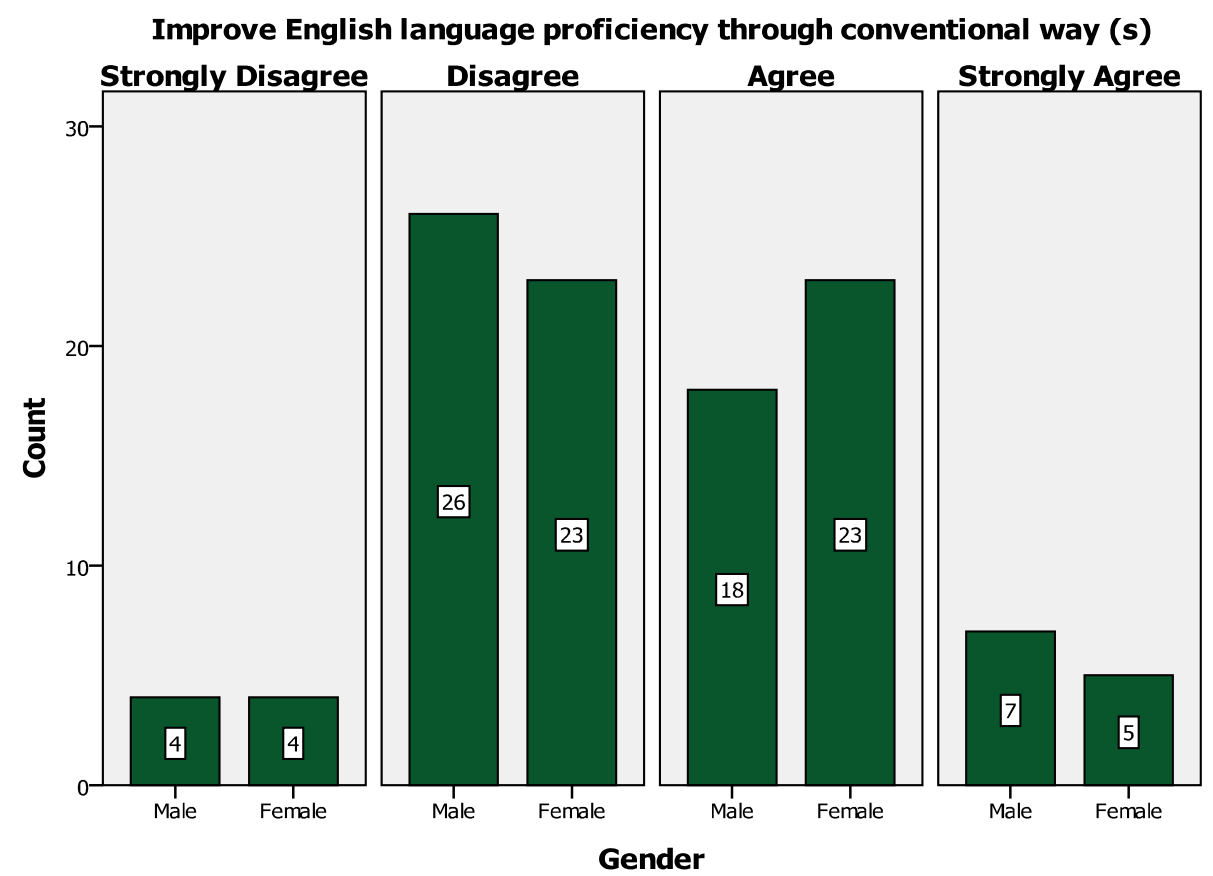

Figure 4.2.4. Distribution of male and female students' attitudes towards the improvement of their English proficiency through conventional classroom learning

\subsection{Findings of the Second Research Question}

Figure 4.2.5. shows the distribution of male and female students' attitudes towards their enjoyment of the video composition project. $\mathrm{N}=55(50 \%)$ male students and $\mathrm{N}=52(47.2 \%)$ either agree or strongly agree that the video composition project was enjoyable. The scores show that male students enjoy the video composition project compared to the female students. Other than that, there are only $\mathrm{N}=3(2.72 \%)$ female students who disagrees that the video composition is enjoyable, while the male students show $\mathrm{N}=0(0 \%)$. Hence, there are more female students who did not enjoy the video composition project compared to the male students.

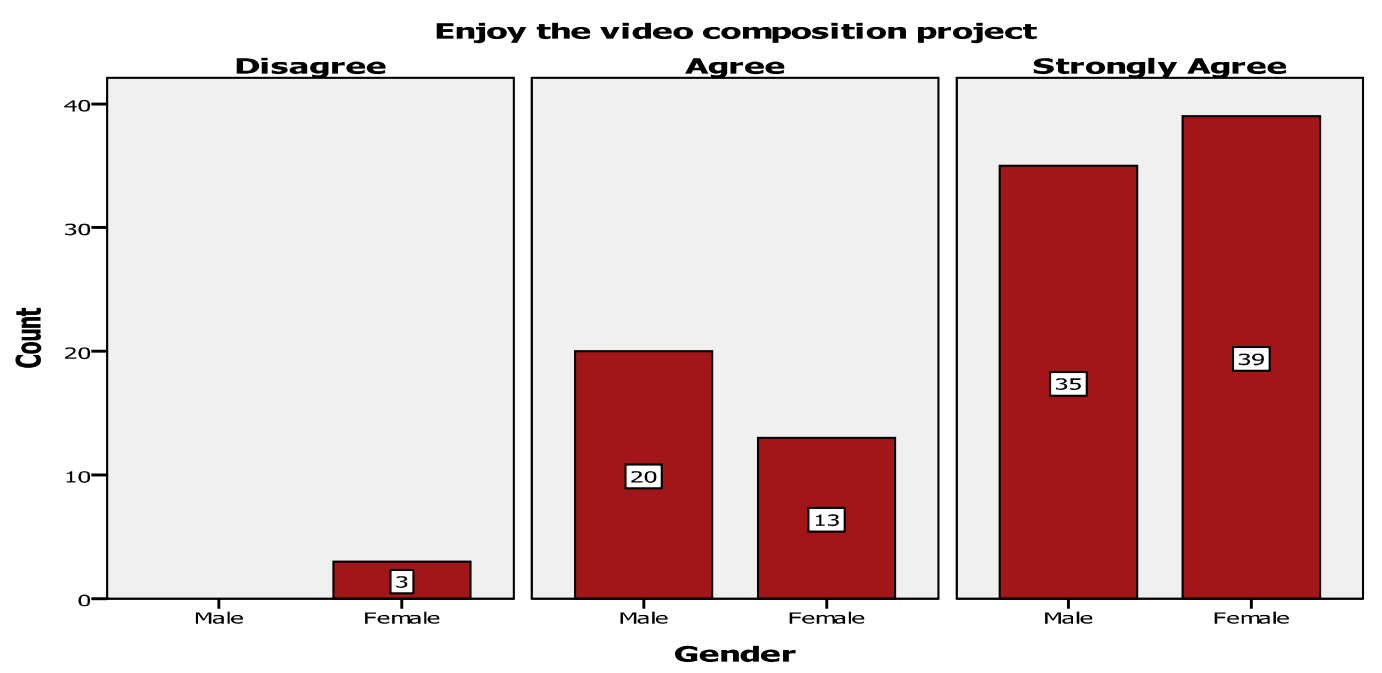

Figure 4.2.5. Distribution of male and female students' attitudes towards their enjoyment of the video composition project

Figure 4.2.6. shows the distribution of male and female students' attitudes towards their usage of the English language during the video project. $\mathrm{N}=52(47.2 \%)$ male students and $\mathrm{N}=52(47.2 \%)$ female students either agree or strongly agree that they used more English language during the video composition project. The male and female students show equal agreement that they use more English during the video composition project. Besides that, there are $\mathrm{N}=3(2.7 \%)$ males students and $\mathrm{N}=3(2.7 \%)$ female students who disagree. Thus, a very small amount of male and female students equally disagree that they use more English during the video composition project. 


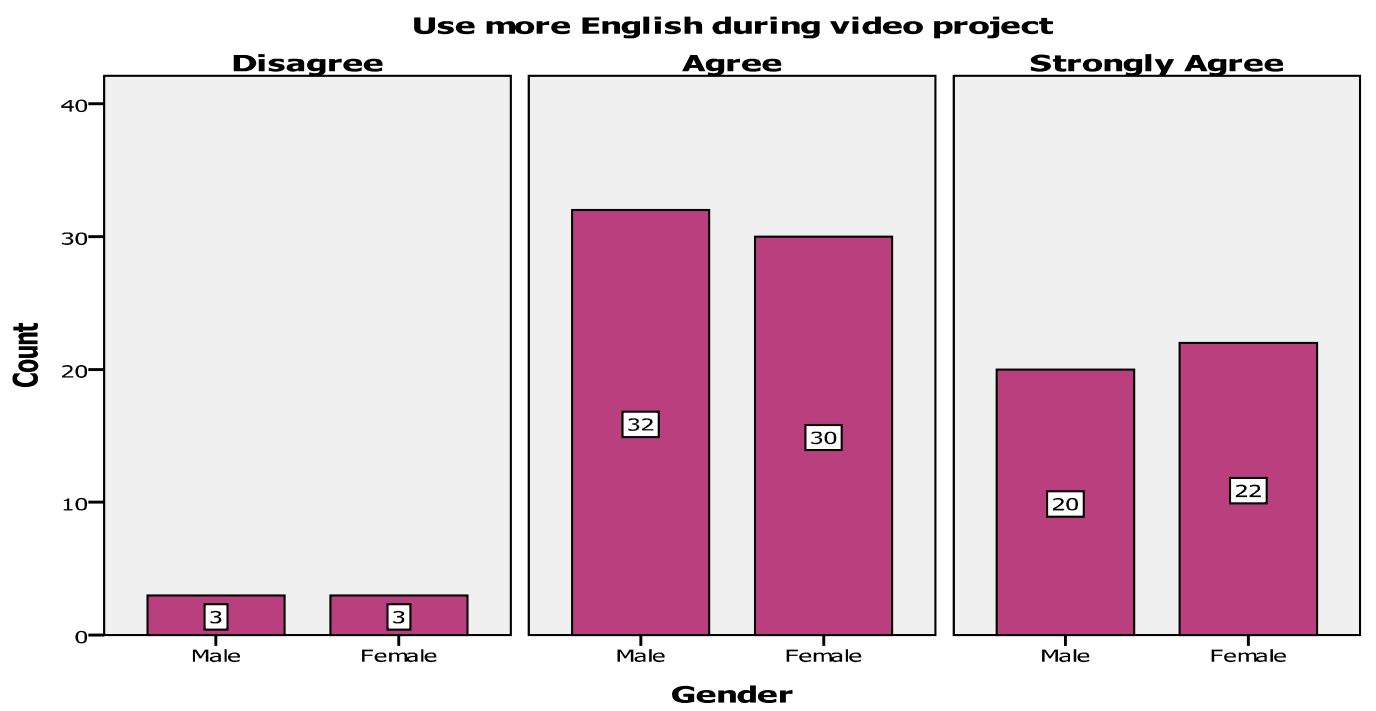

Figure 4.2.6. Distribution of male and female students' attitudes towards the usage of English during the video composition project

Figure 4.2.7. shows the distribution of male and female students' attitudes towards the increase of their motivation to use English after the video composition project. $\mathrm{N}=53(48.1 \%)$ male students and $\mathrm{N}=52(47.2 \%)$ female students who either agree or strongly agree that their motivation to use the English language increased after the video composition project. There are more male students who agree that the video composition project helped them to increase their motivation to use English. On the other hand, there are $\mathrm{N}=2(1.8 \%)$ male students and $\mathrm{N}=3(2.7 \%)$ female student who disagree. Thus, there are more female students who do not feel motivated to use English after the video composition project.

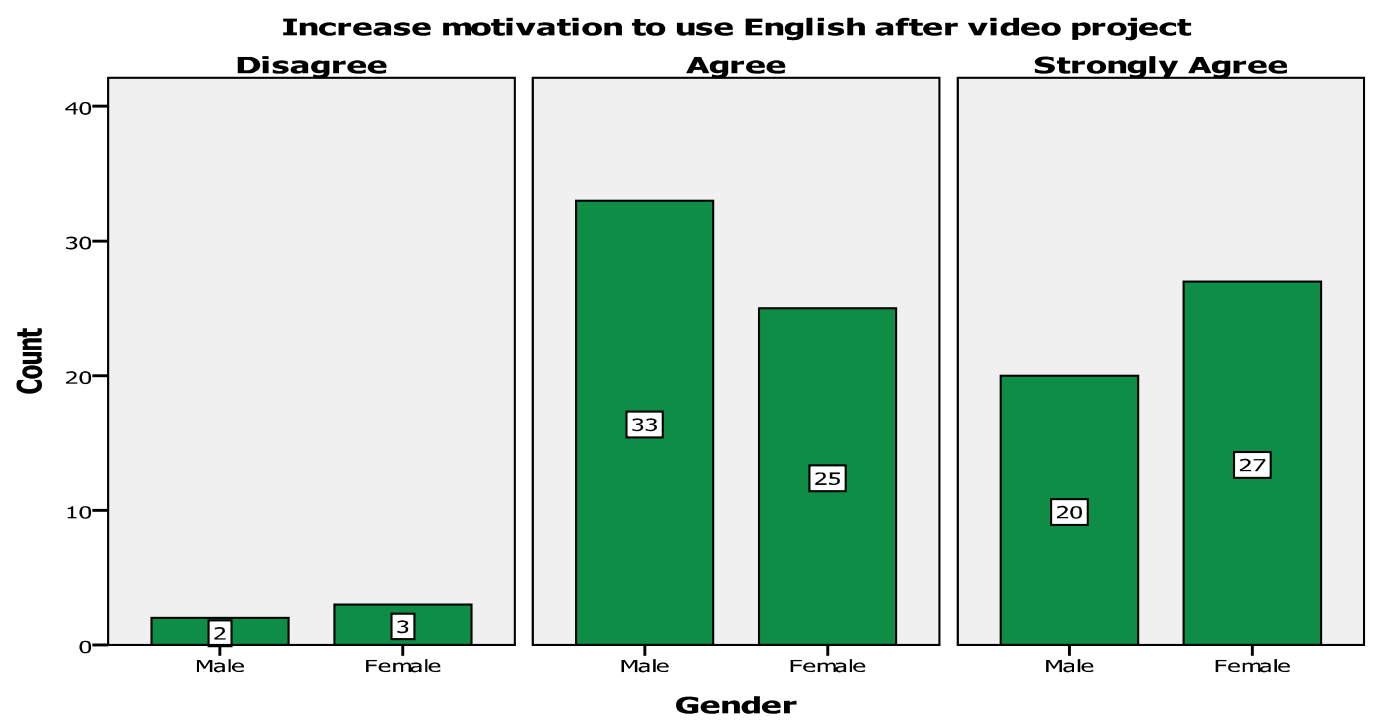

Figure 4.2.7. Distribution of male and female students' attitudes towards their motivation to use English after the video composition project

Figure 4.2.8. presents the distribution of male and female students' attitudes towards the improvement in their English language proficiency through the video composition project. $\mathrm{N}=52(47.2 \%)$ male students and $\mathrm{N}=53(48.1 \%)$ female students agree that video composition helps to improve English language proficiency. The male students are outnumbered by the female students by $\mathrm{N}=1$ in terms of agreeing to the statement above. Besides that, $\mathrm{N}=3(2.7 \%)$ male students are $\mathrm{N}=2(1.8 \%)$ female students disagree. There are slightly more male students who disagree that video composition helps to improve English language proficiency. 


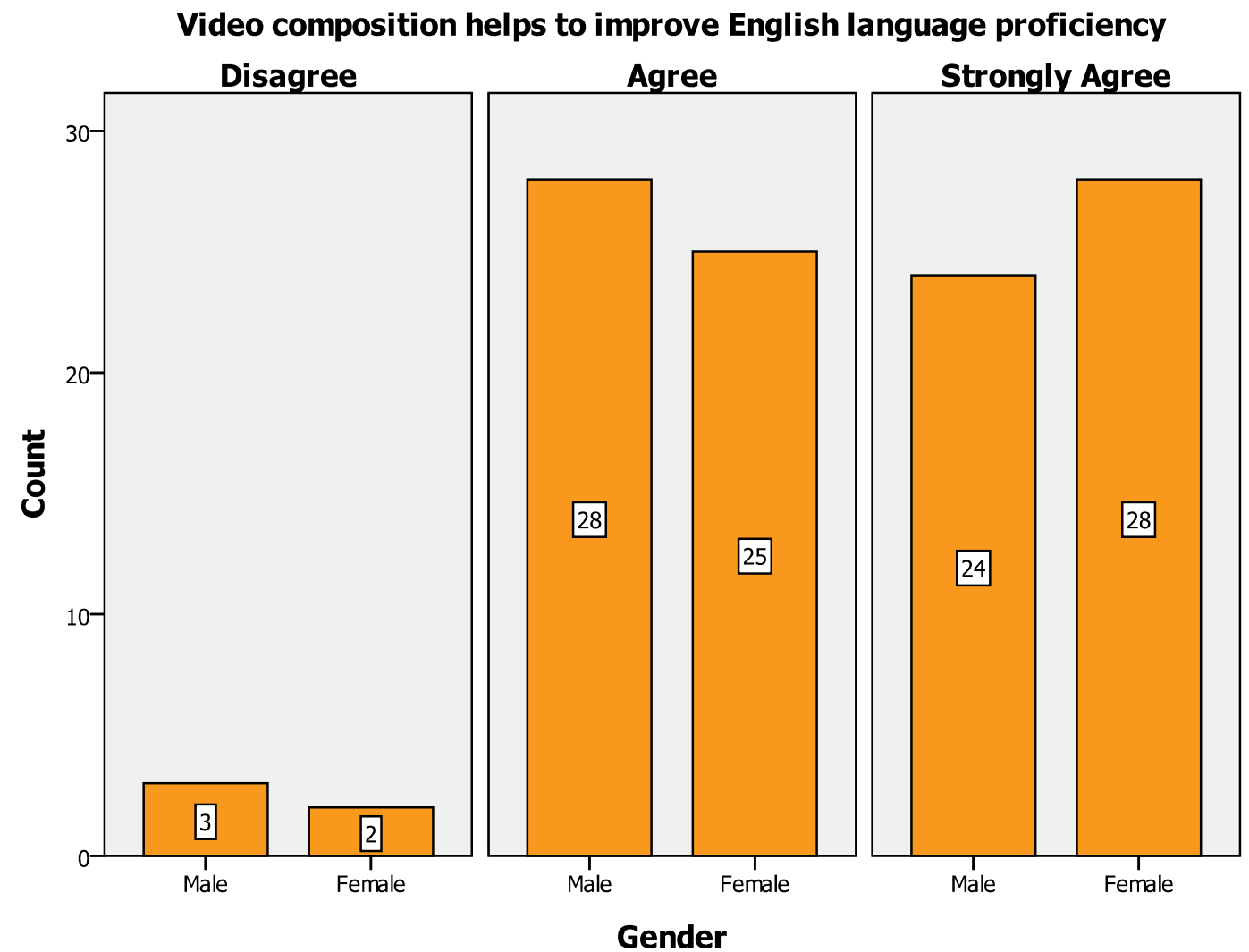

Figure 4.2.8. Distribution of male and female students' attitudes towards the improvement of their English proficiency through the video composition project

Figure 4.2.9. presents the distribution of male and female students' attitudes towards the development of the 4 language skills (reading, writing, speaking and listening) through the video composition project. Both male and female students show the same scores for agree and strongly agree. $\mathrm{N}=52(47.2 \%)$ male and female students equally agree to the variable mentioned above. On the other hand, both the male and female students also equally disagree with the development of the 4 skills through the video composition project. Both male and female students contribute $\mathrm{N}=3$ $(2.7 \%)$ each for disagreeing with the development of the 4 skills.

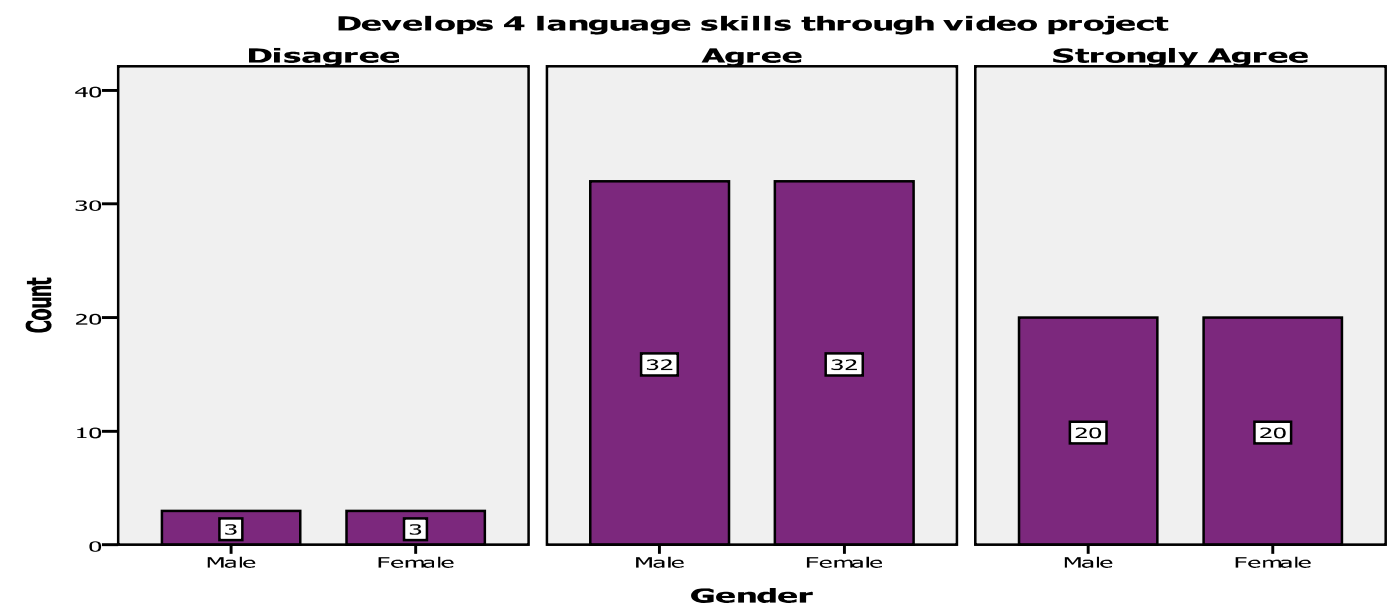

Figure 4.2.9. Distribution of male and female students' attitudes towards the development of the four language skills (reading, writing, listening and speaking) during the video composition project

Figure 4.2.10. presents the distribution of male and female students' attitudes towards their willingness to do the video composition again. $\mathrm{N}=51(46.3 \%)$ male students and $\mathrm{N}=49$ (44.5\%) female students either agree or strongly agree to participate in the video composition project again. The male students are more interested to do the video composition again compared to the female students. On the other hand, a total of $\mathrm{N}=4(3.6 \%)$ male students are $\mathrm{N}=6(5.4 \%)$ female 
students are not interested in participating in the video composition project anymore. Here, the scores show that the female students are more unlikely to participate in the video composition project again.

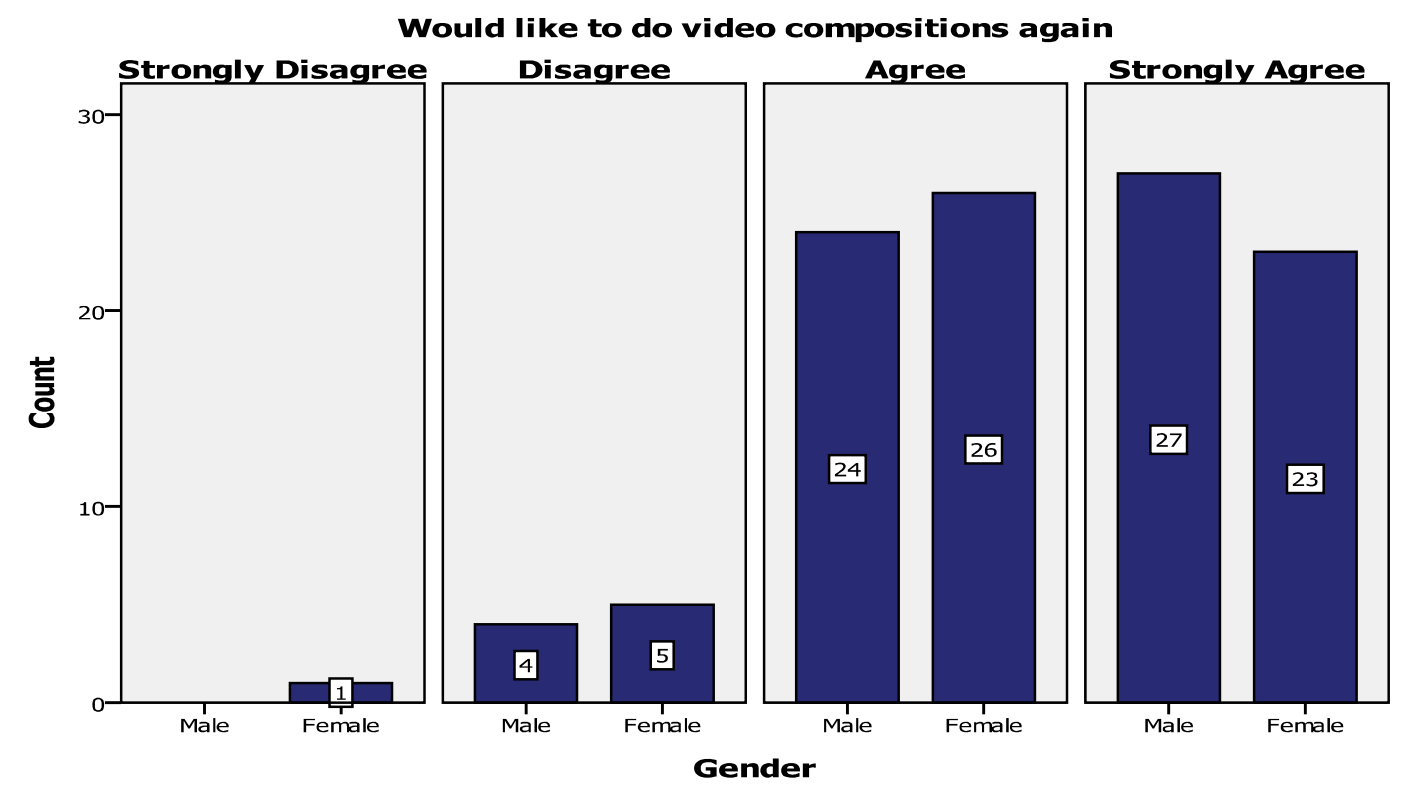

Figure 4.2.10. Distribution of male and female students' attitudes towards participating in the video composition project

again

\subsection{Findings of the Third Research Question}

Figure 4.2.11. presents the distribution of male and female students' attitudes towards their preference of video composition project over conventional classroom exercises. $\mathrm{N}=55(50 \%)$ male students and $52(47.2 \%)$ female students agree or strongly agree that they prefer the video composition project. Besides that, there are $\mathrm{N}=3(2.7 \%)$ female students who either disagree or strongly disagree with the video composition project and prefers conventional classroom exercises, while there are no male students who disagree. This shows that the number of female students who prefer conventional classroom exercises is higher than the male students.

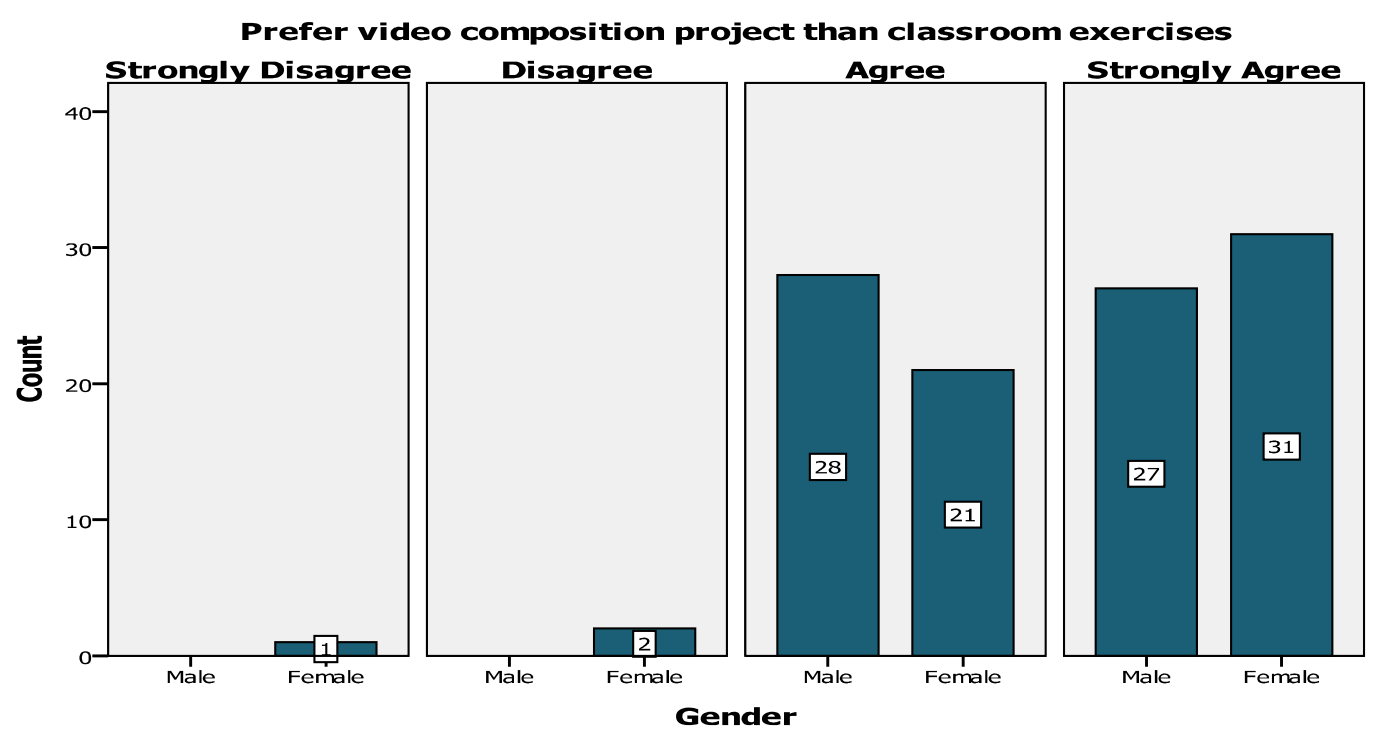

Figure 4.2.11. Distribution of male and female students' attitudes towards their preference of video composition project over conventional classroom exercises

Figure 4.2.12. shows the distribution of male and female students' attitudes towards activities that appeal to their interest. All male and female students $\mathrm{N}=110(100 \%)$ agree and strongly agree that activities that appeal to their interest would help them to learn English language better. 


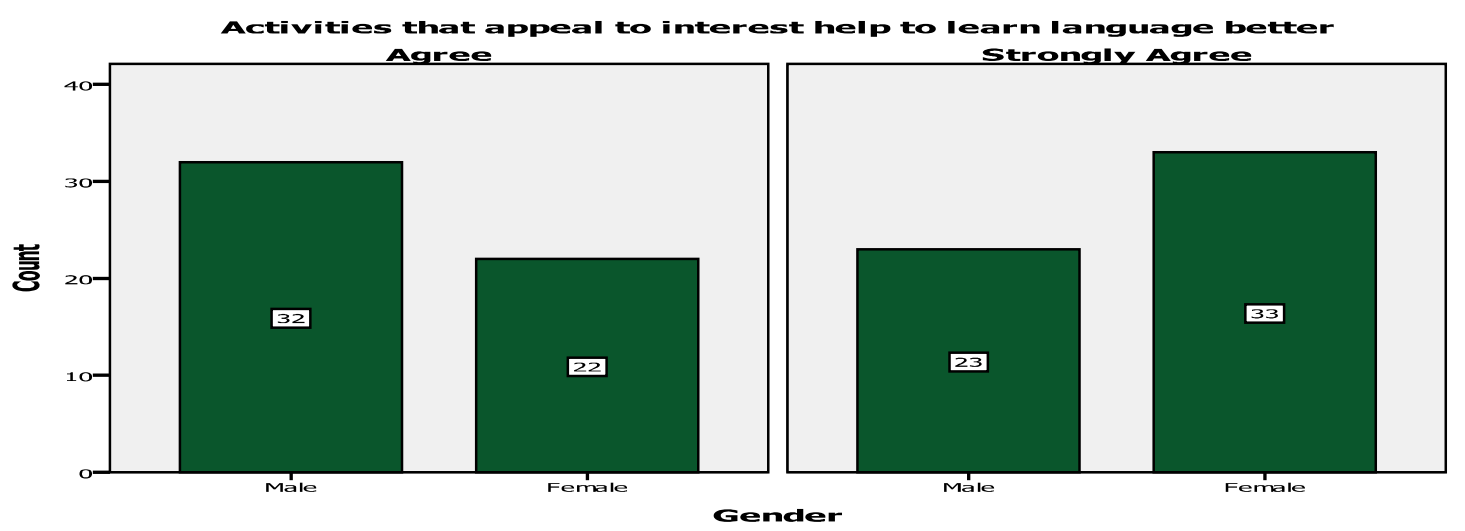

Figure 4.2.12. Distribution of male and female students' attitudes towards activities that appeal to their interest

Figure 4.2.13. shows the distribution of male and female students' attitudes towards whether or not the video composition motivates students to use English more. $\mathrm{N}=54$ (49.1\%) male students and $\mathrm{N}=51$ (46.3\%) female students agree or strongly agree that video composition actually motivates them to use English even more. Thus, there are more male students who agrees to this statement compared to female students. Besides that, there are $\mathrm{N}=1(0.9 \%)$ male student and $\mathrm{N}=4(3.6 \%)$ female students who disagrees with the statement above and feels that the video composition does not help to motivate students to use English more. Here we can see that the number of female students who disagrees is more than the male students.

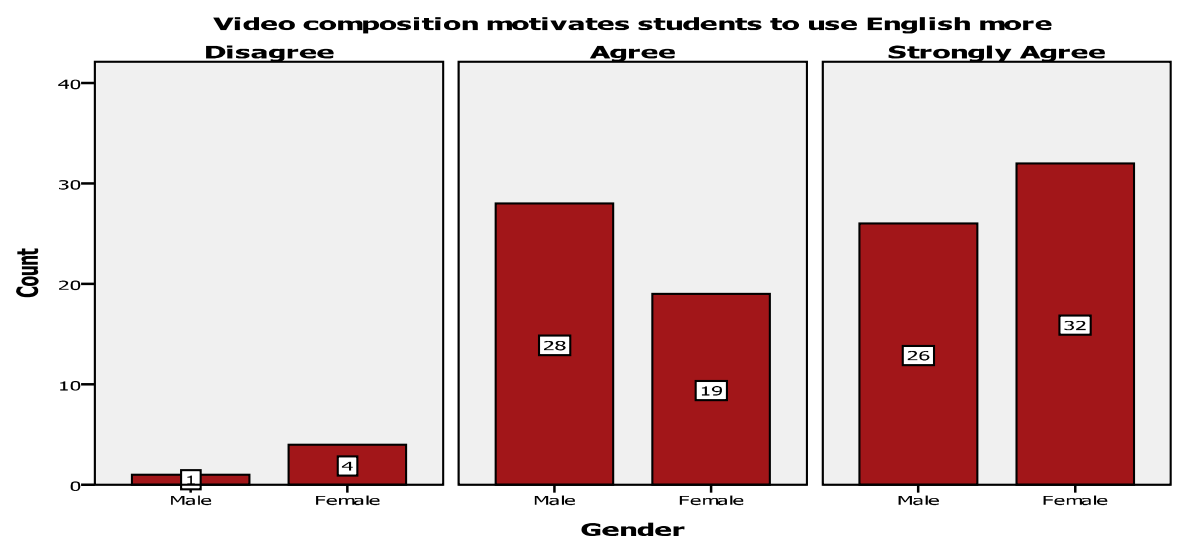

Figure 4.2.13. Distribution of male and female students' attitudes towards whether or not the video composition motivates students to use English more

Figure 4.2.14. shows the distribution of male and female students' attitudes towards their preference in learning English interactively or individually. $\mathrm{N}=55(50 \%)$ male students and $\mathrm{N}=53(48.1 \%)$ female students either agree or strongly agree with learning English interactively compared to learning individually. This shows that more male students prefer interactive learning. On the other hand, there are only $\mathrm{N}=2$ (1.8\%) female students who prefers learning individually in conventional classrooms.

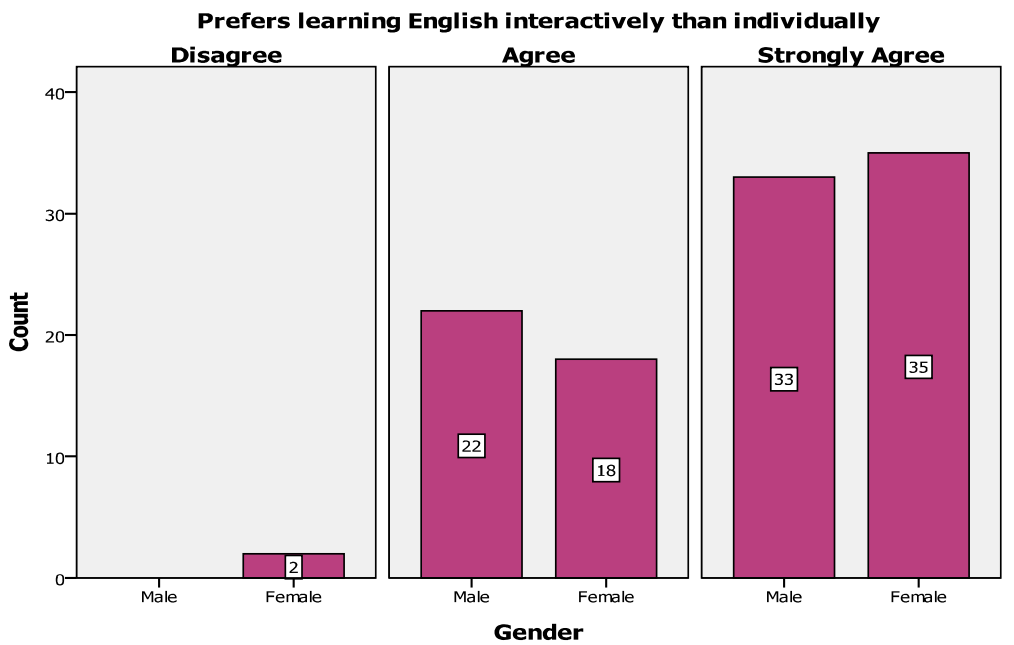

Figure 4.2.14. Distribution of male and female students' attitudes towards their preference in learning English interactively or individually 
4.4 Male And Female Students' Perception Of The Conventional Classroom Teaching, Video Composition Project And The Comparison Between The Former And Latter

The table below presents the mean, standard deviations and standard error means for the students' perception on conventional classroom teaching. The mean for male students is 2.7545 and the female students' mean show 2.8591 . This suggests that both male and female averagely disagrees with the features of the conventional classroom teaching.

Table 4.2.1 Group statistics for male and female students' perception on conventional classroom teaching

\begin{tabular}{|c|c|c|c|c|c|c|}
\hline & Gender & $\mathrm{N}$ & & & Std. Deviation & Std. Error Mean \\
\hline \multirow[t]{2}{*}{ Like English as a subject } & Male & & 55 & 3.1091 & .73718 & .09940 \\
\hline & Female & & 55 & 3.2182 & .59910 & .08078 \\
\hline Enjoy the way(s) of learning & Male & & 55 & 2.6909 & .71680 & .09665 \\
\hline English in class & Female & & 55 & 2.8364 & .68755 & .09271 \\
\hline Motivation to learn English & Male & & 55 & 2.7091 & .65751 & .08866 \\
\hline through conventional way(s) & Female & & 55 & 2.8545 & .77980 & .10515 \\
\hline Improve English language & Male & & 55 & 2.5091 & .81360 & .10971 \\
\hline $\begin{array}{l}\text { proficiency through conventional } \\
\text { way (s) }\end{array}$ & Female & & 55 & 2.5273 & .76629 & .10333 \\
\hline \multirow[t]{2}{*}{ Total Mean } & Male & & 55 & 2.7545 & & \\
\hline & Female & & 55 & 2.8591 & & \\
\hline
\end{tabular}

The table below presents the mean, standard deviations and standard error means for the students' perception on the video composition project. The mean for male students is 3.3969 and the female students' mean show 3.4181. This suggests that both male and female averagely agrees with the features of the video composition project.

Table 4.2.2 Group statistics for male and female students' perception on the video composition project

\begin{tabular}{|c|c|c|c|c|c|c|}
\hline & Gender & $\mathrm{N}$ & & Mean & Std. Deviation & Std. Error Mean \\
\hline \multirow{2}{*}{$\begin{array}{l}\text { Enjoy the video composition } \\
\text { project }\end{array}$} & Male & & 55 & 3.6364 & .48548 & .06546 \\
\hline & Female & & 55 & 3.6545 & .58431 & .07879 \\
\hline \multirow{4}{*}{$\begin{array}{l}\text { Use more English during video } \\
\text { project } \\
\text { Increase motivation to use English } \\
\text { after video project }\end{array}$} & Male & & 55 & 3.3091 & .57325 & .07730 \\
\hline & Female & & 55 & 3.3455 & .58431 & .07879 \\
\hline & Male & & 55 & 3.3273 & .54618 & .07365 \\
\hline & Female & & 55 & 3.4364 & .60135 & .08109 \\
\hline \multirow{2}{*}{$\begin{array}{l}\text { Video composition helps to } \\
\text { improve English language } \\
\text { proficiency }\end{array}$} & Male & & 55 & 3.3818 & .59289 & .07994 \\
\hline & Female & & 55 & 3.4727 & .57267 & .07722 \\
\hline \multirow{2}{*}{$\begin{array}{l}\text { Develops } 4 \text { language skills } \\
\text { through video project }\end{array}$} & Male & & 55 & 3.3091 & .57325 & .07730 \\
\hline & Female & & 55 & 3.3091 & .57325 & .07730 \\
\hline \multirow{2}{*}{$\begin{array}{l}\text { Would like to do video } \\
\text { compositions again }\end{array}$} & Male & & 55 & 3.4182 & .62925 & .08485 \\
\hline & Female & & 55 & 3.2909 & .71162 & .09595 \\
\hline \multirow[t]{2}{*}{ Total Mean } & Male & & 55 & 3.3969 & & \\
\hline & Female & & 55 & 3.4181 & & \\
\hline
\end{tabular}

The figure above presents the mean, standard deviations and standard error means for the students' perception on the video composition project. The mean for male students is 3.3969 and the female students' mean show 3.4181. This suggests that both male and female averagely agrees with the features of the video composition project in helping to improve their English language proficiency more than the conventional classroom teaching methods.

Table 4.2.3 Group statistics for male and female students' perception on the conventional classroom teaching compared to the video composition project

\begin{tabular}{|c|c|c|c|c|c|c|}
\hline & Gender & $\mathrm{N}$ & & & Std. Deviation & Std. Error Mean \\
\hline \multirow{2}{*}{$\begin{array}{l}\text { Prefer video composition project } \\
\text { than classroom exercises }\end{array}$} & Male & & 55 & 3.4909 & .50452 & .06803 \\
\hline & Female & & 55 & 3.4909 & .66312 & .08942 \\
\hline \multirow{2}{*}{$\begin{array}{l}\text { Activities that appeal to interest } \\
\text { help to learn language better }\end{array}$} & Male & & 55 & 3.4182 & .49781 & .06712 \\
\hline & Female & & 55 & 3.6000 & .49441 & .06667 \\
\hline \multirow{2}{*}{$\begin{array}{l}\text { Video composition motivates } \\
\text { students to use English more }\end{array}$} & Male & & 55 & 3.4545 & .53811 & .07256 \\
\hline & Female & & 55 & 3.5091 & .63458 & .08557 \\
\hline \multirow{2}{*}{$\begin{array}{l}\text { Prefers learning English } \\
\text { interactively than individually }\end{array}$} & Male & & 55 & 3.6000 & .49441 & .06667 \\
\hline & Female & & 55 & 3.6000 & .56437 & .07610 \\
\hline \multirow[t]{2}{*}{ Total Mean } & Male & & 55 & 3.4909 & & \\
\hline & Female & & 55 & 3.5500 & & \\
\hline
\end{tabular}


The table below shows the mean scores of the likert scale scores that each sample has recorded for each section. Section A shows that the male students' mean score is 11.0182, while the female students scored 11.4364 over the total score of 16.00. Thus, it means that both their scores are relatively high because it is more than half (8.00). Other than that, in Section B, the mean scores for the male students are 20.3818, while the female students are 20.5091 over the total score of 24.00. Hence, both the scores do not show much difference which are also relatively high since both the scores are more than half (12.00). Last but not least in Section C, the mean scores for male students is 13.9636, while the female students scored 14.2000. Thus, both the scores are relatively high because both the scores are more than half of the total score (16.00).

Table 4.2.3 Likert scale's mean scores according to sections

\begin{tabular}{lllcll}
\hline & & & Group Statistics & \\
& Gender & $\mathrm{N}$ & Mean & Std. Deviation & $\begin{array}{l}\text { Std. Error } \\
\text { Mean }\end{array}$ \\
\hline Section A & Male & 55 & 11.0182 & 2.20682 & .29757 \\
$(16)$ & Female & 55 & 11.4364 & 1.93184 & .26049 \\
Section B (24) & Male & 55 & 20.3818 & 2.39205 & .32254 \\
& Female & 55 & 20.5091 & 2.53035 & .34119 \\
Section C (16) & Male & 55 & 13.9636 & 1.68834 & .22766 \\
& Female & 55 & 14.2000 & 1.99444 & .26893 \\
\hline
\end{tabular}

The table below shows all the scores for (Sig.) and (Sig. [2-tailed]) are more than 0.05. This means that the difference between male and female students' in all the items under different sections which are tested above are not significant. Thus, the male and female students' perception towards the conventional teaching classroom, video composition project and the comparison between the former and latter are almost the same regardless of gender difference.

Table 4.2.4 Independent Samples Test

\begin{tabular}{|c|c|c|c|c|c|c|c|c|c|}
\hline & $\mathrm{F}$ & Sig. & $\mathrm{t}$ & $\mathrm{df}$ & Sig. (2-tailed) & $\begin{array}{c}\text { Mean } \\
\text { Difference } \\
\end{array}$ & $\begin{array}{l}\text { Std. Error } \\
\text { Difference }\end{array}$ & Lower & Upper \\
\hline \multirow{2}{*}{ Section A } & .045 & .832 & -1.057 & 108 & .293 & -.41818 & .39547 & -1.20208 & .36572 \\
\hline & & & -1.057 & 106.142 & .293 & -.41818 & .39547 & -1.20224 & .36587 \\
\hline \multirow{2}{*}{ Section B } & .262 & .610 & -.271 & 108 & .787 & -.12727 & .46952 & -1.05794 & .80339 \\
\hline & & & -.271 & 107.661 & .787 & -.12727 & .46952 & -1.05797 & .80343 \\
\hline \multirow{2}{*}{ Section C } & .671 & .415 & -.671 & 108 & .504 & -.23636 & .35235 & -.93478 & .46206 \\
\hline & & & -.671 & 105.135 & .504 & -.23636 & .35235 & -.93500 & .46227 \\
\hline
\end{tabular}

\subsection{Discussion}

There are three research objectives in this study. The first objective is to identify the male and female students' attitude towards the conventional classroom teaching. The second objective of this study is to identify the male and female students' attitudes towards the video composition project. Last but not least, the third objective of this study is the male and female students' preference towards the video composition project compared to the conventional classroom teaching.

The first objective of this study is the male and female students' attitude towards the conventional classroom teaching. From the data analysis in the previous chapter, it is revealed that the majority of the students are interested in the learning of the English language as a subject in school. The mean score for male students is 2.7545, while the female students' mean score is 2.8591 . The mean scores are relatively low considering the score of 3.0 and above suggest a positive agreement towards the particular section that is surveyed. Although their interest towards English as a subject may be high but the motivation to use the language on a daily basis is still very low. This could be cause of the unsuitable teaching strategies that are implemented in the classroom. Students are not engaged in the conventional classroom as the teaching methods that are applied may be uninteresting for the students. As Kennedy (2005) mentioned, the practices that the teachers devise in the teaching environment are often criticized, while having different reformers focusing on various problems. Some think of the process of learning as dull and dreary, while some think that classroom life as boring, uninteresting, unimportant, or unsubstantial. The male and female students' opinions show no 
significant difference, suggesting that regardless of gender, they are not excited about the conventional classroom teaching methods and find it not useful to improve their English language proficiency.

As for the second objective of this study, the information of male and female students' attitude towards the video composition project is gathered. From the data analysis in the previous chapter, we can see that the male and female students show a high agreement towards the features of the video composition project. The means scores for both male and female is above the score of 3.00. Thus, it suggests that the students are actually excited about the video composition project due to its many features such as, audio and visual aids, the relativity of the subject dealt with and its interactivity that may occur between student and student or student and technology. Mallardi and Brings (2008) suggests that the fundamental needs of the new classroom instructional paradigm are social engagement, active involvement, interactive learning, custom content, and competitive play. All that is mentioned are the features that the video composition project offers since the two video composition projects touch on students' interests (favourite music video) and their experiences (social issues among young adults). The students involved also agree with the suggestion that video composition projects like the one they have participated in contributes to the improvement of their English language proficiency and motivates them to further use the English language. As Killen (1998) had stated, "the greater the amount of time students spend actively working on a subject and thinking about it, the greater their learning." Sjoberg (2006) added, "... the more people appear to be having fun, the greater the level of participation, regardless of any language difficulties". Other than that, they agree to the development of the four language skills throughout the process of accomplishing the video project. Moreover, (Edge, 1993) also supported this idea, "The more students use their language skills for enjoyment, the more language ability they are likely to acquire." He also stated that an action research just like how we are conducting is a rigorous investigation which sets out to improve the quality of experience and outcome available to participants in a given situation, while also enhancing their ability to articulate an understanding of what they have learned, thus increasing their potential to continue to develop in this and other situations, as well as contributing to the sources of knowledge available to others. Arthur (1999) claims that, video can give students realistic models to imitate for role-play; can increase awareness of other cultures by teaching appropriateness and suitability; can strengthen audio/visual linguistic perceptions simultaneously; can widen the classroom repertoire and range of activities; can help utilize the latest technology to facilitate language learning; can teach direct observation of the paralinguistic features found in association with the target language; can be used to help when training students in ESP related scenarios and language; can offer a visual reinforcement of the target language and can lower anxiety when practicing the skill of listening." In this section, the male and female students also show no significant difference in their opinions towards the video composition project. Thus, whether the students are male or female, they are able to perform better in the target language when they are given something that they are interested to work on. Hence, this helps to improve their knowledge of the language and knowledge of world at the same time.

Finally, the third objective of this study is to identify male and female students' preference towards improving English language proficiency through video composition compared to conventional classroom teaching. The results of the data analysis show that the students, regardless male or female, prefers the video composition project than the conventional classroom teaching. This result is proven with the relatively high mean scores shown by both male and female students. Both the male and female students produced an average mean score above 3.40. This shows that the students are more excited to learn, given a task which is authentic and meaningful to them. This is very much unlike the conventional classroom teaching where students are not given the opportunity to exploit their full potential of learning. Waller (1932) stated that the subject matter used in school was boring and irrelevant to the real world outside of the classroom. Decades later, Hoetker and Ahlbrand (1969) reviewed a number of studies in which the studies showed that teachers depended a lot on recitations that focused on insignificant facts and did not allow the students the opportunity to think about the content. Here we can see that many teachers are still unaware of the teaching methods used in classrooms no longer engage the students attention. Thus, students find learning to be something that requires too much effort and unappealing. Kilpatrick (1918) argued that the central feature of school life is the purposeful act where he wanted classroom lessons to be conducted according to the projects that students wanted to do. All these that are mentioned would allow students to be more engaged as the students find it more meaningful and will be able to relate to the activities better than the sort of learning activities that the teacher normally conducts or assigns. When the students are able to relate to what they are learning, they learn faster and they learn better. The retention of the things that they have learnt will be even longer as it they can relate their experiences with the given tasks. Heron (1994) finds that advanced organizers based on videos helped learners improve comprehension and aid in the retention of information. It is undeniable that we will learn more when we enjoy what we are learning. Canning (1998) mentioned that videos can make the task, situation or language more authentic. More importantly, video can be used to help distinguish items on a listening comprehension test, aid in the role of recall, help to sequence events, as well as be adapted, edited or changed in order to meet the needs of the language learner.

The Likert scale's mean scores also show that the scores for the video composition is relatively higher than the scores for conventional classroom teaching. Naturally, the students would prefer the video composition project compared to the conventional classroom teaching due to the many features in the video composition that excites the students to participate in the learning process. 


\section{Conclusion}

The main aim of this study is to identify the difference in students' perception of the conventional English language classroom by comparing it with the video composition project between male and female students. This research has been done on 110 Form 4 students of MRSM Kuala Krai which consists of 55 male students and 55 female students. These students have already participated in the video composition project organized by the Faculty of Educational Studies of Universiti Putra Malaysia early July 2012. These students composed two videos based on the theme given which is closely related to their interest and experience. The first theme is 'favourite music video' while the second is 'social issues among young adults'. This research is a quantitative survey research which aims to establish relationships between variables and to explain the how they are related to each other. Other than that, this study also uses the corelational approach for data collection. By using this approach, the relationship between two or more variables is determined and this does not require any sort of manipulation or intervention. A self-administered survey or questionnaire is used to conduct this study. This research uses non-probability sampling which is purposive sampling because they are accessible to the researcher. Subjects are chosen simply because they are easy to recruit. The recorded data will be analyzed using the SPSS software version 1.7. Based on the data collected for this research, descriptive statistics will be used to determine whether the students feel that the use of video composition has aided their proficiency in the English language. The results are presented in tables and simple bar graphs in the form frequency, means, standard deviations, and $\mathrm{t}$ - test. At the end of the research, the results obtained will then be examined and related with the past research findings.

The factors of the rise and fall of the English language proficiency among students are numerous. Nevertheless, you cannot deny that one of the biggest contributing factors is the classroom activities. It is only natural that students are attracted to the subjects that they find interesting, just like the rest of us who are more engaged with the subjects that appeal to us.

There difference between male and female students' preference is not significant. Thus, gender difference does not really affect their preference in learning as they are both interested in activities that are appeals to their interesting and meaningful to their learning experience.

Teachers and curriculum developers will have to make an effort to revise the educational content, classroom activities along with the teaching strategies that would engage students' interest to promote better learning of the target language, in this case, English as a second language.

\subsection{Recommendations}

This study acts as a platform for other researchers to conduct follow - up studies in investigating the male and female students' perception of improving their English language proficiency through video composition of a bigger sample of students which may involve primary school, secondary school and or tertiary institution students.

A further study can also be conducted to the same sample of students to determine why students' English language proficiency is still low. A pre and post-test can also be done to determine the effectiveness of a new teaching methodology.

Furthermore, other similar studies could be done to urban students as the students in this sample come from rural areas and the result could be compared. This could offer a wider perspective on the differences between these two groups of students, if there is any.

In addition, further studies could be carried out in order to find out if there is any significant relationship between students' improvement in their English language proficiency and motivation or selection of materials or other factors that might contribute to the improvement of the students' English language proficiency.

Last but not least, similar studies can also be conducted by employing both questionnaire and interview. The findings might be different with the addition of an interview analysis. Moreover, additional information and extra clarification on the same subject matter could be obtained. As a result, the findings would be more valid.

\section{References}

Adanza, E. G. (1995). Research Methods: Principles and Applications, Rex Book Store, Inc., Manila.

Briggs-Evsion, N. (2006). English on film: Late night filler or legitimate learning tool? TEFL ASIA: Phonics. January, ( $3^{\text {rd }}$ Ed.), 29.

Canning, C. (1998). Visual support and language teaching. TESOL Arabia News, 5(4): 3-4

Creswell, J. W. (2003). Research Design: Qualitative, Quantitative and Mixed Methods Approaches (2 ${ }^{\text {nd }}$ Ed.). Thousand Oaks, CA: Sage.

Danial, C. (2000), A Writers Guide To Research and Developmental Proposal. Retrieved fom www.education.astate.edu.

Dornyei, Z. (2001). Teaching and Researching Motivation. Harlow, Longman.

Edge, J. (1993). Essentials of English language teaching. Singapore, Longman. 
Edge, J. (2003). Augmenting the discourse of own research, In J. Hull, J. Harris and P.

Daraswang (Eds). (---). Research in ELT: Proceedings of the International Conference (pp.38-47). King Mongkut's University of Technology Thonburi, Thailand.

Fraenkel, J. R., \& Wallen, N. E. (2008). How to design and evaluate research in education. (7 ${ }^{\text {th }}$ Ed.). New York, NY: Mc Graw Hill.

Gigory O. (2008). Speaking Proficiency Level, Reference and Education: Languages, Ezine Articles.

Hagener, M. \& Töteberg, M. (2002). Film: An International Bibliography. Stuttgart: Metzler.

Herron, C. (1994). An investigation of the effectiveness of using an advance organizer to introduce video in the foreign language classroom." Modern Language Journal, 78, 190-198.

Herron, C, Hanley, J. \& Cole, and S. (1995). A comparison study of two advance organizers for introducing beginning foreign language students to video. Modern Language Journal, 79(3), 387-394.

James Hoetker and William P. Ahlbrand, Jr. (1969), The Persistence of the Recitation, American Education Research Association.

John, P. (2010). Embodied Memory and Curatorship in Children's Digital Video Production, 9, (pp. 22-35), University of Waikato.

Karl, P. (2004). The Grammar of Science, Dover Pheonix Editions.

Kelly, L., \& Watson, A. K. (1986). Speaking with confidence and skill. New York, Harper \& Row Press.

Kennedy, Mary M. (2005), Inside Teaching : How Classroom Life Undermines Reform, Library of Congress Cataloging - in - Publilcation Data.

Killen, R. (1998). Effective teaching strategies: Lessons from research and practice, (2nd ed). Katoomba, NSW, Social Science Press.

Kilpatrick, William Heard (1918). The Project Method, Teachers College Record.

Mark Mallardi \& Kent Brings (2008), Keeping Students Engaged in the Classroom, NSSEA Publications.

Mill, N. (1999). Developing specific support materials to accompany feature films on video for self-access language learning. MA thesis, King Mongkut's University of Technology Thonburi, Bangkok.

Murray, G. (2003). Narrative research: Life stories informing ELT. In J. Hull, J.Harris and P. Daraswang (Eds), Research in ELT: Proceedings of the International Conference (pp.105-116). King Mongkut's University of Technology Thonburi, Thailand.

Noraini, I. (2010). Penyelidikan dalam Pendidikan. Kuala Lumpur: McGraw-Hill.

Taffa, T.(2010). Research Methods, Guidelines and Formats, Adama University.

Nordquist, R. (2009), English as a Second Langauge, grammar.about.com.

Vincent, R. (2010), Video Production Program Benefits Both Students and School. Tech Directions, 7(1).

Thornbury, S. (2005), How to teach speaking. Harlow, England: Longman.

Seliger, H. W., \& Shohamy, E. (1990). Second Language Research Methods. Oxford: Oxford University Press.

Sjoberg, J. (2006). Join the club! English Teaching Professional. 46, 53-55.

Susan, M. and Voogt, J. (2011), Facilitating Digital Video Production in the Language Arts Curriculum, (pp.709-726), University of Twente.

Willard, W.W. (1932), The Sociology of Teaching, State College, Pennsylvania.

Wood, D. J. (1995). Good video movies for teaching English as a Foreign or Second Language. Bulletin of the International Cultural Research Institute of Chikushi Jogakuen College, 6, 105-125. 


\section{COMPOSITION AMONG MRSM KUALA KRAI STUDENTS}

Tick on the boxes provided below according to your preference:
(1) Strongly disagree
(2) Disagree
(3) Agree
(4) Strongly agree

1. Male ( ) Female ( )

$\underline{\text { Section A }}$ - Your opinion on English language learning in the normal everyday classroom setting (conventional classroom teaching).

\begin{tabular}{|c|c|c|c|c|c|}
\hline No & Description & 1 & 2 & 3 & 4 \\
\hline 2 & I like English as a subject in class. & & & & \\
\hline 3 & I enjoy the way(s) I learn English in class. & & & & \\
\hline 4 & $\begin{array}{l}\text { The way(s) I learn English in class motivates me to } \\
\text { learn English even more. }\end{array}$ & & & & \\
\hline 5 & $\begin{array}{l}\text { I believe learning English in the normal classroom } \\
\text { helped me to improve my English language } \\
\text { proficiency. }\end{array}$ & & & & \\
\hline
\end{tabular}

$\underline{\text { Section B }}$ - Your opinion about the video composition project.

\begin{tabular}{|c|c|c|c|c|c|}
\hline No & Description & 1 & 2 & 3 & 4 \\
\hline 6 & I enjoyed the video composition project. & & & & \\
\hline 7 & $\begin{array}{l}\text { During the video project, I used more English than I } \\
\text { used to. }\end{array}$ & & & & \\
\hline 8 & $\begin{array}{l}\text { After the video project, I feel more motivated to use } \\
\text { English. }\end{array}$ & & & & \\
\hline 9 & $\begin{array}{l}\text { Learning English through video composition improves } \\
\text { my English language proficiency. }\end{array}$ & & & & \\
\hline 10 & $\begin{array}{l}\text { I developed language skills (reading, writing, listening } \\
\text { and speaking) during the process of producing videos. }\end{array}$ & & & & \\
\hline 11 & I would like to do video compositions again. & & & & \\
\hline
\end{tabular}

$\underline{\text { Section } \mathbf{C}}$ - Your preference towards the video composition project compared to the conventional classroom teaching.

\begin{tabular}{|c|l|l|l|l|l|}
\hline No & \multicolumn{1}{|c|}{ Description } & 1 & 2 & 3 & 4 \\
\hline 12 & $\begin{array}{l}\text { I prefer to do English video composition projects } \\
\text { compared to English exercises given in the classroom. }\end{array}$ & & & & \\
\hline 13 & $\begin{array}{l}\text { I believe language activities that appeal to my interest } \\
\text { help me to learn English language better. }\end{array}$ & & & \\
\hline 14 & $\begin{array}{l}\text { I believe English video compositions motivate me to } \\
\text { use English more than my English exercises done in } \\
\text { classrooms. }\end{array}$ & $\begin{array}{l}\text { I prefer learning English interactively compared to } \\
\text { learning it by doing exercises individually. }\end{array}$ & & & \\
\hline 15
\end{tabular}

